\title{
DIALLEL ANALYSIS AND PREDICTION OF UNTESTED MAIZE SINGLE CROSS HYBRIDS
}

\author{
ANÁLISE DIALÉLICA E PREDIÇÃO DE HÍBRIDOS SIMPLES DE MILHO NÃO \\ TESTADOS
}

\author{
José Lidércio MATIAS JÚNIOR ${ }^{1}$; Maurício Carlos KUKIㄹ Carlos Alberto SCAPIM $^{3}$; \\ Ronald José Barth PINTO \\ 1. Hybrid Breeder at Limagrain - Brazil. 2. PhD Student at Genetic and Plant Breeding Post Graduate Program (PGM) - State \\ University of Maringá (UEM), Brazil. Author for correspondence: mcarloskuki@ gmail.com. 3. Professor at State University of Maringá \\ (UEM), Brazil. 4. Professor at State University of Maringá (UEM), Brazil.
}

\begin{abstract}
Popcorn (Zea mays everta) is a popular snack food and very appreciated in Brazil, presenting higher aggregate value when compared with field corn. The aim of this study were to identify superior inbred lines and single crosses hybrids $(\mathrm{SH})$ for popcorn traits, as well as the prediction of the performance of untested single cross hybrids. Sixteen maize inbred lines were crossed in a 9x7 partial diallel, but it was possible to evaluate 47 single crosses in two distinct locations. Predicted genetic values, diallel analysis and the prediction of untested HS were performed by mixed models. Deviance effects for treatments $\mathrm{x}$ locations were considered non-significant $(p>0.05)$ for grain yield (GY) and popping expansion (PE), showing an average performance from the HS in the locations. Inbred lines P5-1, P3.3T, GER-P3, P9-1, P12-2 and GER-P12 were selected considering the general combining ability, and should be used for obtaining superior genotypes. Based on the non-additive effects, the single hybrid P3.3T x GERP-P12 was selected for grain yield and popping expansion, and could be exploited in future trials. Neither of the untested single crosses showed desirable performance for grain yield and popcorn expansion.
\end{abstract}

KEYWORDS: Diallel analysis. Inbred lines. Mixed models. Popping expansion.

\section{INTRODUCTION}

Popcorn (Zea mays everta) is a popular snack food and it is very appreciated in Brazil, presenting higher aggregate value when compared with field corn. Popping expansion is conferred by pericarp resistance and grain moisture, differing from the field corn and being classified as specialty corn, although both belong to the same genus and species (LEONELLO et al., 2009; DE CARVALHO et al., 2013). When popcorn grains are exposed under heat, the oil and moisture content make pressure over pericarp, bursting it and exposing the endosperm, the so-called "popcorn flower".

According with Cruz et al. (2015), among the 477 maize cultivars available for Brazilian farmers at 2015/16 growth season, only the open pollinated variety RS-20 and the topcross hybrid IAC 125 are indicated for popcorn production. The lack of genotypes that aggregate agronomic and quality traits, associated with low production technology, are the main problems that limits the economical raise of the popcorn national market, favoring seed and grain importation (AMARAL JUNIOR et al., 2010; SILVA et al., 2013). Considering this scenario, the generation of new genotypes able to be used as popcorns, especially to small farmers and industries, it is essential for this specialty corn in Brazil.

The development of popcorn hybrids depends on genetic distance and gene complementation effect, thus, it is necessary to select inbred lines based on genetic effects and heterotic groups in order to obtain single cross hybrids with superior characteristics (HALLAUER et al., 2010). Diallel analysis is one of the most used techniques to obtain genetic information in any breeding program. This controlled mating system allows the estimation of the general combining ability (GCA) and the specific combining ability (SCA), which are associated to the additive and non-additive genetic effects (GRIFFING, 1956). According to the genetic base of the parents involved, the results of the diallel analysis allows the selection of parents for development of superior genotypes.

In situations with a high number of inbred lines, diallel systems results on a large quantity of single crosses for field evaluation. The most expensive part of a plant breeding program is comparing this crosses in field trials, since it is essential to evaluate them in multiple environments for years and different growth seasons (FRITSCHENETO et al., 2010; HALLAUER et al., 2010). 
Therefore, this situation may lead on unbalanced data, especially due to differences between seed production and germination, soil fertility, pests, diseases and adverse climatic conditions, that affect the genotype development on field conditions.

It is essential, in any breeding program, a precise estimation of genetic components for accurate selection among a large data set, for development and recommendation of new improved genotypes (PIEPHO et al., 2008). Considering unbalanced data sets in annual and perennial species, the estimation and maximization of genetic gains can be achieved by mixed linear models (MLM) using REML/BLUP (restricted maximum likelihood/best linear unbiased predicted) procedure (PATTERSON; THOMPSON, 1976; SEARLE et al., 1992; RESENDE, 2002). Thus, it is also possible through MLM to predict the performance of untested hybrids in diallel crosses, using the information about the pedigree of the inbred lines or genetic distance based on molecular markers, allowing breeders to select single hybrids based on their performance without testing them in field trials (BERNARDO, 1996).

The aim of the present study was to select, based on their general and specific combining ability, inbred lines and single crosses with superior values for popcorn traits and to predict the performance of untested single crosses.

\section{MATERIAL AND METHODS}

Sixteen maize inbred lines were selection from the State University of Maringá breeding program (Table 1). The lines were divided in two groups for a partial diallel scheme, with nine inbred lines on group I and seven inbred lines on group II. Groups were divided according with genetic base, grain type, and based on previous experiments.

Table 1. Groups, origin and number from the inbred lines used on the single cross formation.

\begin{tabular}{cccccc}
\hline & Group I & & & Group II \\
\hline Inbred line & Origin & Number & Inbred line & Origin & Number \\
\hline P3.1-2 & CMS 42 & 1 & GER-P3 & Unknown & Angela \\
P3.3T & CMS 42 & 2 & GER-P10 & Unknown & 3 \\
P5-1 & UEM J1 & 3 & GER-P11 & Unknown & 4 \\
P8.1.1 & Zaeli & 4 & GER-P12 & Jade & 5 \\
P8.2 & Zaeli & 5 & GER-P13 & Maradona population & 6 \\
P8.2 MULT & Zaeli & 6 & GER-P14 & Colombiana population & 7 \\
P9-1 & IAC 112 & 7 & & & \\
P11-1 & IAC 125 & 8 & & & \\
P12-2 & IAC 125 & 9 & & & \\
\hline
\end{tabular}

The sixteen inbred lines were grown in 10 meters' rows, 0.9 meters spaced between rows and 0.20 meters between plants, in the second growth season of 2012 at Fazenda Experimental de Iguatemi, located at Maringá/PR. Due to low seed production, it was possible to obtain enough seed for evaluating 47 single hybrids among the 63 possible crosses.

Two trials were carried out in the main crop season of 2012/13. The first one was evaluated at Fazenda Experimental de Iguatemi, State University of Maringá (lat 23 $25^{\prime} \mathrm{S}$; long $51^{\circ} 57^{\prime} \mathrm{O}$, alt $550 \mathrm{~m}$ ) located in Maringá/PR, in a soil characterized as Dystrophic Red Latosol (DRL). The second one was evaluated at Fazenda Escola of State University of Londrina PR (lat $23^{\circ} 22^{\prime} \mathrm{S}$; long $51^{\circ} 22^{\prime} \mathrm{O}$, alt 566 $\mathrm{m})$, located in Londrina/PR, in a soil characterized as Eutrophic Red Latosol (ERL). Climate of both regions is $\mathrm{Cfa}$, according to the Köppen classification, with an annual average temperature of $19^{\circ} \mathrm{C}$ and an annual rainfall of $1500 \mathrm{~mm}$.
The experiments were arranged in a complete randomized blocks with common treatments, as proposed by Pimentel Gomes and Guimarães (1958). The 47 regular treatments were divided in groups, with three commercial controls that were used as the common treatments between groups, with three replications. The hybrids IAC 125, IAC 112 and Jade were used as commercial checks.

Experimental plots were consisted by 5 meters' single row, spaced 0.9 meters between rows and 0.20 meters between plants. In Maringá, sowing fertilization was done with $280 \mathrm{~kg} \mathrm{ha}^{-1}$ of 08-20-20, and in Londrina the sowing fertilization was done with $250 \mathrm{~kg} \mathrm{ha}^{-1}$ of 04-14-08. Twenty days after seed germination, side-dressing fertilization was performed with $50 \mathrm{~kg} \mathrm{ha}^{-1}$ of urea. At 45 days after plant emergence, a thinning operation was performed to adjust the row stand to five plants per meter, totalizing 55.555 plants $\mathrm{ha}^{-1}$. Both experiments were performed according with normal agronomic practices. 
The following traits were evaluated: average plant height $(\mathrm{PH}$, in $\mathrm{cm})$ from six competitive plants; average ear height $(\mathrm{EH}$, in $\mathrm{cm})$ from six competitive plants; grain yield (GY, in $\mathrm{kg} \mathrm{ha}^{-1}$ ), corrected to a $15 \%$ moisture content; popping expansion ( $\mathrm{PE}$, in $\mathrm{mL} \mathrm{g}^{-1}$ ), determined in laboratory using an electric popping device developed by EMBRAPA - Centro Nacional de Pesquisa e Desenvolvimento de Instrumentação Agrícola (CNPDIA). Samples of each plot were composed by grains from ten kernels, manually hulled and discarding the both ends of the kernels. Popping expansion measurement was performed by the ratio of the volume from $30 \mathrm{~g}$ grain after popping, at $280^{\circ} \mathrm{C}$ for 2.5 minutes and with 13 to $14 \%$ of moisture content, with two replications per plot. A $2000 \mathrm{~mL}$ graduated cylinder was used to measure the popcorn volume after expansion.

Experimental data was analyzed with the following mixed linear model, where:

$$
Y=W_{l}+T_{e}+X_{\beta}+S_{a}+Z_{g}+I_{p}+\varepsilon
$$

$\mathrm{y}$ is the vector from observed data $(y \times 1), l$ is the fixed effect vector $(l \times 1)$ from the environments, $\beta$ is the fixed effect vector $(\beta \times 1)$ from the replications-experiments, $a$ is the fixed effect vector $\left(\begin{array}{lll}a & \mathrm{x} & 1\end{array}\right)$ from the environments-replicationsexperiments interaction, $g$ is the random effect vector $(g \times 1)$ for regular and common treatments, $p$ is the random effect vector $(p \times 1)$ for the interaction between treatments and environments, $\mathrm{W}, \mathrm{T}, \mathrm{X}, \mathrm{S}, \mathrm{Z}$ and $\mathrm{I}$ are the incidence matrixes from the associated $l, e, \beta, a, g$, and $p$ parameters, and $\epsilon$ is the residual random effect vector. The significance of the random effects was performed by deviance analysis using likelihood ratio test (LTR), with and without $g$ and $p$, using the chi-square with one degree of freedom at $5 \%$ of probability. Fixed effects of the model were tested though ANOVA, using $\mathrm{F}$ test at $5 \%$ of probability.

The predicted genotypic values $(\mu+\mathrm{g})$ were obtained through the sum of the genotypic values (BLUPs) with the average of fixed effects (environments and replicates). These values $(\mu+\mathrm{g})$ were used for treatment comparison and for diallel analysis through mixed models. For the diallel analysis using the IV model proposed by Griffing (1956) adapted for partial diallel's (CRUZ et al., 2012), the following mixed linear model was considered:

$$
Y=X_{\beta}+Z_{1} g_{1}+Z_{2} g_{2}+Z_{3} s
$$

which $\mathrm{y}$ is the vector $(\mathrm{y} \times 1)$ of the predicted genotypic values $(\mu+\mathrm{g})$ for the characteristic, $\beta$ is the fixed effect vector $(\beta \times 1)$ for the environments, $g_{l}$ is the random effect vector $\left(g_{l} \times 1\right)$ related with the general combining ability effects $\left(\widehat{g_{2}}\right)$ for the inbred lines on group I (GCAI), $g_{2}$ is the random effect vector $\left(g_{2} \times 1\right)$ related with the general combining ability effects $\left(\hat{g}_{j}\right)$ for the inbred lines on group II (GCAII), $s$ is the random effect vector ( $s$ $x$ 1) for the specific combining ability (SCA) effects $\left(s_{i j}\right)$ for the tested single cross hybrids between the inbred lines from the two groups, and $\mathrm{X}, \mathrm{Z}_{1}, \mathrm{Z}_{2}$ and $\mathrm{Z}_{3}$ are the incidence matrixes from the associated $\beta$, $g_{1}, g_{2}$ and $s$ parameters, respectively.

The solution for the fixed and random effects followed the equation system proposed by Henderson (1984):

$$
\left[\begin{array}{c}
\beta^{o} \\
\hat{g}_{1} \\
\hat{g}_{2} \\
\hat{s}
\end{array}\right]=\left[\begin{array}{cccc}
X^{\prime} X & X^{\prime} Z_{1} & X^{\prime} Z_{2} & X^{\prime} Z_{3} \\
Z_{1}^{\prime} X & Z_{1} Z_{1}+A_{1}{ }^{-1} \gamma_{1} & Z_{1}^{\prime} Z_{2} & Z_{1}^{\prime} Z_{3} \\
Z_{2}^{\prime} X & Z_{2}^{\prime} Z_{1} & Z_{2} Z_{2}+A_{2}{ }^{-1} \gamma_{2} & Z_{2}^{\prime} Z_{3} \\
Z_{3}^{\prime} X & Z_{3}^{\prime} Z_{1} & Z_{3}^{\prime} Z_{2} & Z_{3} Z_{3}+A_{3}^{-1} \gamma_{3}
\end{array}\right]^{-1}\left[\begin{array}{c}
X^{\prime} y \\
Z_{1}^{\prime} y \\
Z_{2}^{\prime} y \\
Z_{3}^{\prime} y
\end{array}\right]
$$

which $y_{1}=\frac{\sigma_{e}^{2}}{\sigma_{G C A I}^{2}}, \quad y_{2}=\frac{\sigma_{e}^{2}}{\sigma_{G C A I I}^{2}}$ and $y_{3}=\frac{\sigma_{e}^{2}}{\sigma_{S C A}^{2}}$.

Variance components were solved using the Expectation-Maximization (EM) algorithm from REML method. Based on initial arbitrary values for error, GCAI, GCAII and SCA variance components, the solutions for $\beta, g_{1}, g_{2}$ and $s$ were obtained and used again for obtaining new estimations of variance components and so on, until convergence is achieved. Identity matrices were used on the matrixes of coefficients of relatedness between the inbred lines in group I $\left(\mathrm{A}_{1}\right)$, group II $\left(\mathrm{A}_{2}\right)$ and between the single cross hybrids $\left(\mathrm{A}_{3}\right)$.

Prediction of untested single crosses for phenotypic values and SCA estimation were performed considering the methodology proposed by Bernardo (1996). Predicted genotypic values $(\mu+\mathrm{g})$ from the tested single crosses were corrected for the fixed effects $(\beta)$ using the proposed equation:

$$
\hat{y}_{p}=\left(Z_{3}^{\prime} Z_{3}\right)^{-1} Z_{3}^{\prime}\left(y-X_{\beta}\right)
$$

which $\hat{y}_{p}$ is the vector of the phenotypic means corrected by the fixed effects, $Z_{3}$ is the incidence matrix from the parameter associated with the tested single crosses, $\mathrm{X}$ is the incidence matrix from the fixed effects, $\mathrm{y}$ is the vector ( $\mathrm{y}$ x 1) of estimated means for the characteristic, $\beta$ is the fixed effect vector $(\beta \times 1)$ associated with the environments. Prediction of untested single hybrids were made using the following expression:

$$
\widehat{y}_{n t}=C V^{-1} \hat{y}_{p}
$$

which $\hat{y}_{n t}$ being the performance vector of untested single hybrids, $\mathrm{C}$ is the matrix of covariance's between the tested and untested hybrids, $\mathrm{V}^{-1}$ is the variance-covariance matrix between the tested hybrids, and $\hat{y}_{p}$ is the vector of the phenotypic 
means corrected by the fixed effects. Estimation of SCA from the untested hybrids was performed using SCA values from the tested hybrids at $\hat{y}_{p}$ vector.

For all traits evaluated, analysis of variance and deviance were performed in SAS software version 9.3 (SAS, 2013), considering significance when $p<0.05$. Diallel analysis and the prediction of untested single hybrids were performed using a function programmed on R software 3.3.1 (R CORE TEAM, 2016).

\section{RESULTS AND DISCUSSION}

The result of the deviance analysis for the random effects and the ANOVA for the fixed effects is presented in Table 2. The deviance values for the treatments differed significantly by the chi-square test at 5\% probability for all the evaluated traits, indicating high genetic variability between the single hybrids. Considering the results for treatments $\mathrm{x}$ environments interaction, the deviance values were considered not significant for GY and $\mathrm{PE}$, reflecting the similar performance of the treatments in both environments, an indication that the selection of the superior's single hybrids can be made considering the average performance in both environments. Hybrid performance differed for $\mathrm{PH}$ and $\mathrm{EH}$ according to the environment, indicating that selection must be made for each environment separately.

Considering GY and PE, the commercial checks obtained average predicted values of $3.42 \mathrm{t}$ $\mathrm{ha}^{-1}$ and $27.18 \mathrm{~mL} \mathrm{~g}^{-1}$, whilst the single hybrid were superiors for GY $\left(3.68 \mathrm{t} \mathrm{ha}^{-1}\right)$ but presented lower values for PE $\left(22.71 \mathrm{~L} \mathrm{~g}^{-1}\right)$. For GY, these values can be considered superior when compared with Vieira et al. (2011) and Silva et al. (2013), although, the values obtained for PE are below than those observed by Arnhold et al. (2010) and Rossato Júnior et al. (2013), but very similar from the data observed by authors with experimental (VIEIRA et al., 2011) and commercial (LEONELLO et al., 2009) single hybrids. The predicted values for $\mathrm{PH}$ and EH were similar between the single hybrids and the commercial checks, which are already established in the popcorn market. These traits are important in maize hybrids because are correlated with plant lodging and flowering time (JI et al., 2006).

Table 2. Deviance analysis, p-values and general means for the characteristics evaluated in both environments, at 2012/2013 growth season.

\begin{tabular}{|c|c|c|c|c|c|c|c|c|}
\hline \multirow{3}{*}{ Effects } & \multicolumn{6}{|c|}{ Random effects } & \multirow{2}{*}{\multicolumn{2}{|c|}{$\mathrm{EH}^{4}$}} \\
\hline & \multicolumn{2}{|c|}{$\mathrm{GY}^{1}$} & \multicolumn{2}{|c|}{$\mathrm{PE}^{2}$} & \multicolumn{2}{|c|}{$\mathrm{PH}^{3}$} & & \\
\hline & Dev. $^{5}$ & LRT $^{6}$ & Dev. & LRT & Dev. & LRT & Dev. & LRT \\
\hline Treatments & 5450.3 & $35.3^{*}$ & 1751.9 & $57.1^{*}$ & 2672.8 & $32.1^{*}$ & 2541.7 & $21.9^{*}$ \\
\hline Treat. ${ }^{7}$ x Env. ${ }^{8}$ & 5482.7 & $2.9^{\text {ns }}$ & 1807.8 & $1.2^{\mathrm{ns}}$ & 2699.4 & $5.5^{*}$ & 2556.2 & $7.4^{*}$ \\
\hline Complete model & 5447.4 & & 1750.7 & & 2667.3 & & 2534.3 & \\
\hline \multicolumn{9}{|c|}{ Fixed Effects } \\
\hline Effects & G.L. & \multicolumn{2}{|r|}{ GY } & \multicolumn{2}{|l|}{$\begin{array}{c}\text { PE } \\
00001^{*}\end{array}$} & PH & \multicolumn{2}{|r|}{ EH } \\
\hline Env & 1 & \multirow{2}{*}{\multicolumn{2}{|c|}{$\begin{array}{c}0.0001^{*} \\
0.1928\end{array}$}} & \multirow{2}{*}{\multicolumn{2}{|c|}{$\begin{array}{c}0.0001 \\
0.0146\end{array}$}} & $0.0001^{*}$ & \multirow{2}{*}{\multicolumn{2}{|c|}{$0.0001^{*}$}} \\
\hline Experiments & 3 & & & & & 0.0021 & 0.0002 & \\
\hline $\operatorname{Rep}^{9} / \operatorname{Exp}^{10}$ & 8 & \multicolumn{2}{|r|}{0.0001} & \multicolumn{2}{|l|}{0.4844} & 0.1430 & \multirow{2}{*}{\multicolumn{2}{|c|}{0.1860}} \\
\hline Env/Rep/Exp & 11 & & \multicolumn{2}{|l|}{0.0001} & 0.007 & \multirow{2}{*}{\multicolumn{2}{|c|}{$\frac{0.0001}{122.83}$}} \\
\hline \multicolumn{2}{|c|}{ Single hybrids $\mu+g$} & \multicolumn{2}{|r|}{3684.91} & \multicolumn{2}{|l|}{22.71} & 217.74 & & \\
\hline Commercial & $s \mu+g$ & \multicolumn{2}{|r|}{3421.36} & \multicolumn{2}{|l|}{27.18} & 217.88 & \multicolumn{2}{|r|}{122.49} \\
\hline
\end{tabular}

${ }^{*}$ Significant at 5\% probability, considering the Chi-squared test for random effects and F-test for fixed effects. ${ }^{\text {ns }}$ No significant at 5\% probability, considering the Chi-squared test for random effects and F-test for fixed effects. ${ }^{1} \mathrm{GY}$ : Grain Yield $\left(\mathrm{kg} \mathrm{ha}^{-1}\right) .{ }^{2} \mathrm{PE}$ : Popping expansion $\left(\mathrm{mL} \mathrm{g}^{-1}\right)$. ${ }^{3} \mathrm{PH}$ : Plant height $(\mathrm{cm}) .{ }^{4} \mathrm{EH}$ : Ear height $(\mathrm{cm}) .{ }^{5}$ Deviance. ${ }^{6}$ Likelihood Ratio Test. ${ }^{7}$ Treatments. ${ }^{8}$ Environments. ${ }^{9}$ Replications. ${ }^{10}$ Experiments.

The predicted genotypic values $(\mu+\mathrm{g})$ are presented in Table 3. Considering GY, the single hybrids P3.3T x GER-P15 (2x7 - $\left.4.68 \mathrm{t} \mathrm{ha}^{-1}\right), \mathrm{P} 5-1 \mathrm{x}$ GER-P11 (3x3 - 5.24 t ha $\left.{ }^{-1}\right)$ and P5-1 x GER-P14 $\left(3 \times 6-5.32 \mathrm{t} \mathrm{ha}^{-1}\right)$ were the most productive, whereas for PE the single hybrids P3.3T x GER-P12 (2x4 - $\left.27.98 \mathrm{~mL} \mathrm{~g}^{-1}\right)$, P12-2 x GER-P12 (9x4 - 28.98 $\left.\mathrm{mL} \mathrm{g}^{-1}\right)$ and the topcross hybrid IAC $125(29.48 \mathrm{~mL}$ $\mathrm{g}^{-1}$ ) showed superior values. For AP, the single hybrids P3.1-2 x GER-P15 (1x7 - $211.6 \mathrm{~cm})$ and P12.2 x GER-P14 (9x6 - $229.2 \mathrm{~cm})$ presented higher values in Maringá and Londrina, respectively. Besides PH and EH are strongly correlated traits, the best single hybrids for $\mathrm{EH}$ differs in both locations, being P11.1 x GER-P10 (8x2 - $122.5 \mathrm{~cm})$ and P8.2 MULT x GER-P13 (6x5 - $129.3 \mathrm{~cm})$ for Maringá and Londrina. This result is mainly explained by the significant interaction between 
treatments $\mathrm{x}$ environments for $\mathrm{PH}$ and $\mathrm{EH}$, which affects differently the performance of the genotypes.

Table 3. Predicted genotypic values $(\mu+\mathrm{g})$ for the single cross hybrids and for the commercial checks evaluated in two environments, at 2012/2013 growth season.

\begin{tabular}{|c|c|c|c|c|c|c|}
\hline \multirow{2}{*}{ Treatment } & \multirow{2}{*}{$\frac{\mathrm{GY}^{1}}{\text { Average Env }}$} & \multirow{2}{*}{$\frac{\mathrm{PE}^{2}}{\text { Average Env }}$} & \multicolumn{2}{|c|}{$\mathrm{PH}^{3}$} & \multicolumn{2}{|c|}{$\mathrm{EH}^{4}$} \\
\hline & & & Maringá & Londrina & Maringá & Londrina \\
\hline $1 \times 1$ & 4314.1 & 20.83 & 209.2 & 227.5 & 120.1 & 126.7 \\
\hline $1 \times 3$ & 3038.3 & 21.29 & 210.3 & 225.1 & 119.8 & 125.8 \\
\hline $1 \times 4$ & 3932.5 & 26.65 & 209.5 & 226.4 & 118.4 & 127.3 \\
\hline $1 \times 5$ & 4224.5 & 22.82 & 209.9 & 226.0 & 119.9 & 126.9 \\
\hline $1 \times 6$ & 3493.1 & 25.42 & 211.2 & 224.6 & 121.1 & 124.9 \\
\hline $1 \times 7$ & 3059.5 & 23.12 & 211.6 & 225.4 & 121.0 & 126.0 \\
\hline $2 \times 2$ & 3981.2 & 21.59 & 207.7 & 228.4 & 116.9 & 129.1 \\
\hline $2 \times 3$ & 4369.5 & 25.12 & 209.7 & 225.6 & 119.9 & 127.2 \\
\hline $2 \times 4$ & 4534.3 & 27.98 & 210.6 & 225.8 & 120.7 & 126.3 \\
\hline $2 \times 6$ & 4148.6 & 25.98 & 209.6 & 228.5 & 122.1 & 128.2 \\
\hline $2 \times 7$ & 4687.4 & 20.62 & 209.5 & 225.6 & 119.4 & 126.1 \\
\hline $3 \times 2$ & 4072.4 & 17.70 & 209.7 & 225.4 & 119.4 & 126.6 \\
\hline $3 \times 3$ & 5245.7 & 20.62 & 209.3 & 226.4 & 120.1 & 126.6 \\
\hline $3 \times 5$ & 4634.8 & 15.56 & 209.0 & 226.7 & 119.5 & 128.3 \\
\hline $3 \times 6$ & 5320.4 & 14.48 & 211.3 & 225.5 & 122.8 & 126.0 \\
\hline $3 \times 7$ & 4307.5 & 12.49 & 209.6 & 226.0 & 119.6 & 126.8 \\
\hline $4 \times 1$ & 4418.2 & 19.73 & 208.8 & 227.6 & 117.9 & 128.4 \\
\hline $4 \times 2$ & 2354.8 & 20.50 & 208.2 & 225.4 & 117.2 & 127.3 \\
\hline $4 \times 3$ & 3668.2 & 24.18 & 207.3 & 227.4 & 117.7 & 127.3 \\
\hline $4 \times 4$ & 3280.3 & 26.17 & 210.2 & 224.1 & 119.5 & 124.6 \\
\hline $4 \times 5$ & 3718.3 & 21.42 & 211.7 & 223.4 & 119.3 & 125.0 \\
\hline $4 \times 6$ & 3245.0 & 24.03 & 210.1 & 225.1 & 120.9 & 124.3 \\
\hline $4 \times 7$ & 3511.5 & 20.96 & 210.0 & 225.7 & 118.4 & 126.3 \\
\hline $5 \times 2$ & 3258.5 & 21.73 & 208.0 & 225.7 & 120.9 & 122.9 \\
\hline $5 \times 4$ & 3743.0 & 21.27 & 208.4 & 225.3 & 119.7 & 125.5 \\
\hline $5 \times 5$ & 4249.8 & 14.98 & 210.1 & 225.7 & 120.0 & 125.6 \\
\hline $5 \times 6$ & 3900.3 & 24.18 & 210.6 & 225.1 & 119.9 & 125.7 \\
\hline $5 \times 7$ & 4682.4 & 17.44 & 210.5 & 226.1 & 117.6 & 127.4 \\
\hline $6 \times 3$ & 3291.6 & 24.79 & 208.4 & 226.5 & 119.6 & 124.7 \\
\hline $6 \times 4$ & 3723.8 & 21.11 & 208.7 & 225.2 & 119.6 & 122.7 \\
\hline $6 \times 5$ & 3426.2 & 24.64 & 208.7 & 226.2 & 115.7 & 129.3 \\
\hline $6 \times 6$ & 3522.1 & 24.95 & 209.0 & 225.7 & 119.6 & 124.0 \\
\hline $6 \times 7$ & 2798.4 & 24.53 & 210.4 & 225.5 & 122.2 & 123.8 \\
\hline $7 \times 3$ & 3571.1 & 23.15 & 211.1 & 220.8 & 119.2 & 122.8 \\
\hline $7 \times 5$ & 3919.2 & 25.91 & 208.9 & 225.7 & 117.7 & 127.7 \\
\hline $7 \times 6$ & 3570.2 & 26.37 & 208.9 & 224.3 & 118.8 & 124.8 \\
\hline $8 \times 2$ & 2917.9 & 26.68 & 210.7 & 224.7 & 122.5 & 123.1 \\
\hline $8 \times 3$ & 3598.7 & 23.30 & 210.9 & 225.9 & 120.1 & 126.3 \\
\hline $8 \times 4$ & 2291.1 & 25.30 & 209.8 & 225.3 & 119.0 & 126.6 \\
\hline $8 \times 5$ & 3074.6 & 22.38 & 210.3 & 226.6 & 122.1 & 125.2 \\
\hline $8 \times 6$ & 2387.8 & 26.52 & 210.6 & 224.5 & 119.2 & 126.6 \\
\hline $8 \times 7$ & 3131.4 & 23.30 & 209.5 & 227.1 & 121.2 & 126.0 \\
\hline $9 \times 2$ & 2905.4 & 26.37 & 208.8 & 226.3 & 116.0 & 128.3 \\
\hline $9 \times 4$ & 3602.8 & 28.98 & 208.2 & 227.0 & 117.8 & 127.5 \\
\hline $9 \times 5$ & 3615.1 & 24.84 & 208.6 & 228.1 & 121.3 & 125.4 \\
\hline $9 \times 6$ & 3756.7 & 20.24 & 207.3 & 229.2 & 118.3 & 127.4 \\
\hline $9 \times 7$ & 2693.0 & 25.30 & 210.3 & 225.9 & 119.7 & 124.8 \\
\hline IAC 125 & 3493.8 & 29.48 & 209.9 & 225.7 & 118.5 & 126.2 \\
\hline IAC 112 & 3231.6 & 26.78 & 206.2 & 231.4 & 116.8 & 129.4 \\
\hline JADE & 3538.8 & 25.29 & 205.5 & 228.6 & 115.0 & 129.1 \\
\hline
\end{tabular}

${ }^{1}$ GY: Grain Yield $\left(\mathrm{kg} \mathrm{ha}^{-1}\right) .{ }^{2} \mathrm{PE}$ : Popping expansion $\left(\mathrm{mL} \mathrm{g} \mathrm{g}^{-1}\right) .{ }^{3} \mathrm{PH}$ : Plant height $(\mathrm{cm}) .{ }^{4} \mathrm{EH}$ : Ear height $(\mathrm{cm})$.

In popcorn breeding, the principal the predicted genotypic values, it is possible to agronomic characteristics are grain yield and conclude that none of the single hybrid crosses popping expansion (SILVA et al., 2013). Based on presented superior values in both traits, which is in 
agreement with the results obtained by Arnhold et al. (2006) and illustrates the difficulties for obtaining simultaneous positive gain selections, mainly due to the negative correlations. Nevertheless, the hybrid P3.3T x GER-P12 (2x4) presented the third higher values for $\mathrm{PE}$ and is among the six best hybrids for GY $\left(4.53 \mathrm{t} \mathrm{ha}^{-1}\right)$, performing better predicted genotypic values $(\mu+\mathrm{g})$ for these traits than the commercial checks, and can be considered promising for future experiments.

The results from the GCA for the mixed model diallel are shown on Table 4. Based on the
MATIAS JÚNIOR, J. L. et al.

additive effects, it is possible to select for GY the inbred lines P5-1 and P3.3T from group I and the inbred line GER-P3 from group II. Considering PE, the inbred lines P9-1 and P12-2 in group I and GERP12 in group II were found to be superior in terms of frequency of favorable genes with additive effects. For PH and EH, the inbred lines P3.3T from group I and GER-P3 from group II showed the highest GCA effects.

Table 4. General combining ability effects from the group I and group II inbred lines, for the characteristics evaluated at two environments, at 2012/2013 growth season.

\begin{tabular}{|c|c|c|c|c|}
\hline \multirow{2}{*}{ Inbred line } & $\mathrm{GY}^{1}$ & $\mathrm{PE}^{2}$ & $\mathrm{PH}^{3}$ & $\mathrm{EH}^{4}$ \\
\hline & \multicolumn{4}{|c|}{ Group I } \\
\hline P3.1-2 & -150.50 & 0.66 & 0.17 & 0.18 \\
\hline P3.3T & 663.47 & 1.11 & 0.21 & 0.44 \\
\hline P5-1 & 968.85 & -5.68 & 0.08 & 0.40 \\
\hline P8.1.1 & -280.45 & -0.22 & -0.13 & -0.22 \\
\hline P8.2 & 298.22 & -2.56 & -0.08 & -0.15 \\
\hline P8.2 MULT & -369.88 & 1.05 & -0.14 & -0.37 \\
\hline P9-1 & -110.50 & 1.96 & -0.41 & -0.42 \\
\hline P11-1 & -718.05 & 1.58 & 0.17 & 0.22 \\
\hline P12-2 & -301.16 & 2.08 & 0.13 & -0.09 \\
\hline Inbred line & \multicolumn{4}{|c|}{ Group II } \\
\hline GER-P3 & 502.10 & -0.99 & 0.13 & 0.11 \\
\hline GER-P10 & -503.02 & 0.24 & -0.17 & -0.18 \\
\hline GER-P11 & 59.94 & 0.32 & -0.12 & -0.10 \\
\hline GER-P12 & -38.20 & 1.47 & -0.15 & -0.14 \\
\hline GER-P13 & 160.14 & -0.68 & 0.09 & 0.16 \\
\hline GER-P14 & -43.54 & 0.67 & 0.08 & 0.13 \\
\hline GER-P15 & -137.41 & -1.03 & 0.15 & 0.03 \\
\hline Environments & \multicolumn{4}{|c|}{ Fixed effects } \\
\hline Maringá & $3,754.12$ & 23.43 & 209.58 & 119.54 \\
\hline Londrina & $3,754.12$ & 22.90 & 225.86 & 126.07 \\
\hline
\end{tabular}

${ }^{1}$ GY: Grain Yield $\left(\mathrm{kg} \mathrm{ha}^{-1}\right) .{ }^{2} \mathrm{PE}$ : Popping expansion $\left(\mathrm{mL} \mathrm{g}^{-1}\right) .{ }^{3} \mathrm{PH}$ : Plant height $(\mathrm{cm}) .{ }^{4} \mathrm{EH}$ : Ear height $(\mathrm{cm})$.

Popcorn breeding programs seek genotypes that aggregate high grain yield and popping expansion. Based on GCA effects, it is possible to select the best inbred lines with superior additive effects for traits of interest, being a parental in future crosses for hybrids with large agronomic performance for producers and popcorn industry. Inbred line P3.3T showed the higher additive effect for GY and a good positive GCA effect for popping expansion, presenting a great potential for composing new genotypes with superior yield and popping expansion. These results suggest that, using a mixed linear model analysis, it is possible to select genotypes with satisfactory values for both grain yield and popping expansion. Similar results were found by Freitas et al. (2013), which recommended the use of selection index based on REML/BLUP methods for positive gains in grain yield and popping expansion, even with the negative correlation between the characteristics.

The SCA reflects the specificity between the parents involved in crosses, being explained by the effect of complementation between alleles derived from each parent (dominant gene action) and the effect of interactions between alleles of different loci involved in the trait transmission (epistatic gene action). High $\hat{s}_{i j}$ values, regardless of the signal, indicates that the SCA performance were different than the expected based on the GCA of the parents. Although, for selecting the best crosses based on the SCA effects, at least one parent with high GCA should be present at the cross (CRUZ et al., 2012). Furthermore, SCA is also related with the genetic distance between the parents and demonstrate the importance of non-additive interactions to 
complement the performance of the hybrid combination.

The results for SCA effects are presented on Table 5.

Table 5. Specific combining ability effects from the single crosses hybrids, for the characteristics evaluated at two environments, at 2012/2013 growth season.

\begin{tabular}{|c|c|c|c|c|}
\hline Single crosses hybrids & $\mathrm{GY}^{1}$ & $\mathrm{PE}^{2}$ & $\mathrm{PH}^{3}$ & $\mathrm{EH}^{4}$ \\
\hline $1 \times 1$ & 191.25 & -1.34 & 0.12 & 0.10 \\
\hline $1 \times 3$ & -576.04 & -2.10 & -0.03 & -0.04 \\
\hline $1 \times 4$ & 337.31 & 1.65 & 0.07 & -0.01 \\
\hline $1 \times 5$ & 423.52 & 0.16 & -0.01 & 0.09 \\
\hline $1 \times 6$ & -62.19 & 1.27 & -0.03 & -0.04 \\
\hline $1 \times 7$ & -374.88 & 0.74 & 0.16 & 0.16 \\
\hline $2 \times 2$ & 60.79 & -2.16 & 0.11 & -0.03 \\
\hline $2 \times 3$ & -99.98 & 0.90 & -0.06 & 0.14 \\
\hline $2 \times 4$ & 142.04 & 2.42 & 0.14 & 0.13 \\
\hline $2 \times 6$ & -208.04 & 1.36 & 0.35 & 0.59 \\
\hline $2 \times 7$ & 374.27 & -1.90 & -0.18 & -0.18 \\
\hline $3 \times 2$ & -136.35 & 0.42 & -0.03 & -0.02 \\
\hline $3 \times 3$ & 425.41 & 2.93 & 0.05 & 0.08 \\
\hline $3 \times 5$ & -229.08 & -0.66 & -0.02 & 0.18 \\
\hline $3 \times 6$ & 589.41 & -2.82 & 0.19 & 0.35 \\
\hline $3 \times 7$ & -256.47 & -3.08 & -0.06 & 0.00 \\
\hline $4 \times 1$ & 406.66 & -1.53 & 0.16 & 0.16 \\
\hline $4 \times 2$ & -567.38 & -1.95 & -0.21 & -0.06 \\
\hline $4 \times 3$ & 123.32 & 1.25 & -0.05 & 0.01 \\
\hline $4 \times 4$ & -143.37 & 2.01 & -0.09 & -0.12 \\
\hline $4 \times 5$ & 77.22 & -0.31 & -0.05 & -0.19 \\
\hline $4 \times 6$ & -170.94 & 0.81 & -0.01 & -0.04 \\
\hline $4 \times 7$ & 160.74 & -0.41 & 0.04 & -0.08 \\
\hline $5 \times 2$ & -268.21 & 1.22 & -0.22 & -0.19 \\
\hline $5 \times 4$ & -250.10 & -0.28 & -0.20 & 0.03 \\
\hline $5 \times 5$ & 33.81 & -3.95 & 0.06 & -0.01 \\
\hline $5 \times 6$ & -100.40 & 3.02 & 0.06 & 0.00 \\
\hline $5 \times 7$ & 705.84 & -1.46 & 0.17 & -0.05 \\
\hline $6 \times 3$ & -140.98 & 0.67 & 0.01 & -0.07 \\
\hline $6 \times 4$ & 347.15 & -3.62 & -0.16 & -0.38 \\
\hline $6 \times 5$ & -109.31 & 1.42 & -0.07 & -0.03 \\
\hline $6 \times 6$ & 166.42 & 0.49 & -0.10 & -0.25 \\
\hline $6 \times 7$ & -413.28 & 1.63 & 0.09 & 0.19 \\
\hline $7 \times 3$ & -122.47 & -1.60 & -0.41 & -0.44 \\
\hline $7 \times 5$ & 105.71 & 1.75 & -0.03 & 0.06 \\
\hline $7 \times 6$ & -28.05 & 0.96 & -0.26 & -0.25 \\
\hline $8 \times 2$ & 353.67 & 1.94 & 0.00 & -0.01 \\
\hline $8 \times 3$ & 462.13 & -1.13 & 0.23 & 0.09 \\
\hline $8 \times 4$ & -651.06 & -0.37 & -0.06 & -0.03 \\
\hline $8 \times 5$ & -112.47 & -1.05 & 0.17 & 0.15 \\
\hline $8 \times 6$ & -557.14 & 1.43 & -0.14 & -0.07 \\
\hline $8 \times 7$ & 213.67 & 0.08 & 0.08 & 0.19 \\
\hline $9 \times 2$ & -41.53 & 1.23 & -0.04 & -0.13 \\
\hline $9 \times 4$ & 172.53 & 2.45 & -0.02 & 0.03 \\
\hline $9 \times 5$ & 1.30 & 0.69 & 0.14 & 0.14 \\
\hline $9 \times 6$ & 319.10 & -4.59 & 0.12 & 0.00 \\
\hline $9 \times 7$ & -573.53 & 1.41 & 0.03 & -0.17 \\
\hline
\end{tabular}

${ }^{1}$ GY: Grain Yield $\left(\mathrm{kg} \mathrm{ha}^{-1}\right) .{ }^{2} \mathrm{PE}$ : Popping expansion $\left(\mathrm{mL} \mathrm{g} \mathrm{g}^{-1}\right) .{ }^{3} \mathrm{PH}$ : Plant height (cm). ${ }^{4} \mathrm{EH}$ : Ear height (cm). 
Based on the additive effects, the genitors P5-1, P3.3T and GER-P3 were selected for GY. The single hybrids P5.1 x GER-P14 (3x6), P3.3T x GER-P15 (2x7) and P8.1.1 x GER-P3 (4x1) showed the higher $\hat{s}_{i j}$ effect and also presented higher estimated means for GY (Table 3). Although, all these hybrids presented negative $\hat{s}_{i j}$ effects for PE and estimated means below $20 \mathrm{~mL} \mathrm{~g}^{-1}$, indicating negative effects for this characteristic, which is not desirable in popcorn breeding programs (BARRETO et al., 2012).

The $\hat{s}_{i j}$ effects for PE and also for PH and EH were low and close to zero, indicating that the additive effects were more important to the estimated mean. Similar results were also observed by Vieira et al. (2011), highlighting the importance of GCA than SCA for popping expansion. The inheritance of bi-directional dominance may also explain the low participation of non-additive effects for PE (SILVA et al., 2010).

Inbred lines P9-1, P12-2 and GER-P12 had superior additive effects, and the best hybrids for this characteristic should have at least one of these inbred lines. Thus, considering $\hat{s}_{i j}$ effects, the single hybrids P12-2 x GER-P12 (9x4), P3.3T x GER-P12 (2x4) and P9-1 x GER-P13 (7x5) were selected, but only P3.3T x GER-P12 (2x4) showed positive $\hat{s}_{i j}$ effects for GY. Regarding the estimated means (Table 3), this single hybrid was ordered between the six higher means for GY $\left(4.53 \mathrm{t} \mathrm{ha}^{-1}\right)$ and also between the three best ones for PE $\left(27.98 \mathrm{~mL} \mathrm{~g}^{-1}\right)$. Therefore, it is possible to achieve proper GY and PE means in single hybrids by selecting inbred lines with higher additive effects for GY (P3.3T) and PE (GER-P12), allowing a positive $\hat{s}_{i j}$ effect in the single hybrid, evidencing the potential of these inbred lines for popcorn breeding programs.

The results of the estimated means and SCA for the untested single hybrids, as well as Pearson correlation with the predicted genotypic values $(\mu+\mathrm{g})$ and $\hat{s}_{\mathrm{ij}}$ effects obtained from the tested single hybrids, are showed at Table 6 . Considering the selected inbred lines based on general combining ability (Table 4), the untested single crosses P5-1 x GER-P12 (3x4) and P8.2 x GER-P3 (5x1) presented higher performance for GY, with positive effects for SCA. For popping expansion, the single hybrid P9-1 $x$ GER-P12 $(7 \times 4)$ showed positive $\hat{s}_{i j}$ and acceptable estimated mean. For PH and EH, the cross P3.3T $x$ GER-P13 (2x5) was the best hybrid, with estimated means of 219.1 and $125.2 \mathrm{~cm}$, in addition too positive $\hat{s}_{\mathrm{ij}}$ effects. Although, none of the untested single crosses obtained satisfactory performance for GY and PE simultaneously.

Table 6. Estimated means, specific combining ability (SCA) from the untested single crosses, and Pearson correlation between tested and untested single crosses, for the characteristics evaluated at two environments, at 2012/2013 growth season.

\begin{tabular}{ccccccccc}
\hline \multirow{2}{*}{ Untested crosses } & \multicolumn{3}{c}{ Estimated means } & \multicolumn{3}{c}{ SCA } \\
\cline { 2 - 8 } & $\mathrm{GY}^{1}$ & $\mathrm{PE}^{2}$ & $\mathrm{PH}^{3}$ & $\mathrm{EH}^{4}$ & $\mathrm{GY}$ & $\mathrm{PE}$ & $\mathrm{PH}$ & $\mathrm{EH}$ \\
\hline 1x2 & 3975.7 & 41.6 & 218.3 & 124.1 & -202.6 & 19.6 & 0.2 & 0.6 \\
$2 \times 1$ & 3450.7 & 30.5 & 217.9 & 123.1 & -490.7 & 7.7 & 0.1 & 0.2 \\
$2 \times 5$ & 4004.4 & 40.5 & 219.1 & 125.2 & -109.2 & 18.8 & 0.5 & 1.1 \\
$3 \times 1$ & 4086.4 & 33.1 & 218.7 & 124.4 & 154.4 & 11.5 & 0.3 & 0.7 \\
$3 \times 4$ & 4943.5 & 16.2 & 218.3 & 123.6 & 1046.1 & -3.6 & 0.2 & 0.3 \\
$5 \times 1$ & 5007.3 & 9.1 & 218.3 & 123.4 & 1930.7 & -10.4 & 0.2 & 0.2 \\
$5 \times 3$ & 4493.3 & 5.3 & 218.2 & 123.3 & 1928.3 & -14.6 & 0.2 & 0.2 \\
$6 \times 1$ & 4912.6 & 6.6 & 217.6 & 122.2 & 1728.3 & -15.1 & -0.1 & -0.3 \\
$6 \times 2$ & 3813.1 & 13.9 & 217.8 & 122.8 & 840.2 & -9.0 & 0.0 & 0.0 \\
$7 \times 1$ & 3916.3 & 24.6 & 217.6 & 122.7 & 93.9 & 0.6 & -0.1 & -0.1 \\
$7 \times 2$ & 3408.1 & 33.9 & 218.1 & 123.4 & -422.9 & 9.2 & 0.1 & 0.2 \\
$7 \times 4$ & 1483.7 & 48.4 & 218.3 & 124.1 & -2281.1 & 25.2 & 0.2 & 0.5 \\
$7 \times 7$ & 1225.4 & 0 & 214.2 & 115.0 & -2262.5 & -65.0 & -1.3 & -3.6 \\
$8 \times 1$ & 2830.9 & 0 & 215.0 & 116.1 & -777.9 & -57.5 & -1.0 & -3.1 \\
$9 \times 1$ & 2409.3 & 0 & 213.9 & 114.5 & -1034.3 & -63.9 & -1.4 & -3.7 \\
$9 \times 3$ & 3734.1 & 0 & 214.6 & 115.6 & 112.1 & -58.2 & -1.1 & -3.3 \\
\hline Correlation & 0.13 & 0.26 & 0.22 & 0.30 & 0.20 & 0.21 & 0.22 & 0.20 \\
\hline
\end{tabular}

${ }^{1}$ GY: Grain Yield $\left(\mathrm{kg} \mathrm{ha}^{-1}\right) .{ }^{2} \mathrm{PE}$ : Popping expansion $\left(\mathrm{mL} \mathrm{g}^{-1}\right) .{ }^{3} \mathrm{PH}$ : Plant height $(\mathrm{cm}) .{ }^{4} \mathrm{EH}$ : Ear height $(\mathrm{cm})$. 
Correlation values of means and SCA effects between tested and untested single hybrids ranged among 0.13 to 0.30 , being mainly considered of low magnitude. Balestre et al. (2010) observed correlation values between the predicted genotypic values and the observed means of 0.55 to 0.70 and 0.61 to 0.70 for SCA values, with relationship coefficients obtained from microsatellite molecular markers, increasing the technique precision. Schrag et al. (2009) demonstrated that, based with a large data set of molecular markers, single hybrid performance can be predicted efficiently for traits controlled by additive effects, as well as for traits with a large heterosis participation, like grain yield. Thus, prediction of untested single crosses can be a good alternative for breeding programs with a vast number of inbred lines, enhancing the chances for selecting superior genotypes, when pedigree information or relationship matrices through molecular markers are available for using in the model.

\section{CONCLUSIONS}

Based on GCA effects, inbred lines P5-1, P3.3T and GER-P3 were selected for grain yield, whereas P9-1, P12-2 and GER-P12 were selected for popping expansion.

Single hybrid P3.3T x GER-P12 presented superior estimated means and SCA effects, and can be used for future trials.

Considering GY and PE simultaneously, the untested single hybrids presented unsatisfactory performance when compared with the tested single hybrids.

RESUMO: O milho pipoca (Zea mays everta) é um alimento consumido e apreciado em todo o Brasil, apresentando valor comercial superior ao do milho comum. O presente trabalho teve como objetivo identificar linhagens e híbridos simples (HS) com desempenho superior para as principais características relacionadas ao milho pipoca, além da predição do desempenho de híbridos simples não testados. Foi realizado um dialelo parcial 9x7, dos quais apenas 47 HS foram avaliados em dois locais. Os valores genéticos preditos, análise dialélica e a predição dos HS não avaliados foram realizadas via modelos mistos. Os efeitos da deviance na interação tratamentos $x$ locais foram considerados não significativos $(p>0.05)$ para rendimento de grãos $(R G)$ e capacidade de expansão (CE), indicando um comportamento médio dos HS nos ambientes testados. Com base nos efeitos aditivos, as linhagens P5-1, P3.3T, GER-P3, P9-1, P12-2 e GER-P12 foram selecionados e deverão ser usadas na formação de genótipos com desempenho superior. O híbrido P3.3T x GER-P12 foi selecionado por apresentar elevado desempenho específico para rendimento e capacidade de expansão, podendo ser utilizado em futuros experimentos. Entre os híbridos não avaliados, nenhum apresentou desempenho satisfatório para as características avaliadas.

PALAVRAS-CHAVE: Análise dialélica. Linhagens. Modelos mistos. Capacidade de expansão.

\section{REFERENCES}

AMARAL JUNIOR, A. T.; FREITAS-JUNIOR, S. P.; RANGEL, R. M.; PENA, G. F.; RIBEIRO, R. M.; MORAIS, R. C.; SCHUELTER, A.R. Improvement of a popcorn population using selection indexes from a fourth cycle of recurrent selection program carried out in two different environments. Genetics and Molecular Research, v. 9, n. 1, p. 340-347, 2010. https://doi.org/10.4238/vol9-1gmr702

ARNHOLD, E.; MORA, F.; DEITOS, A. Correlaciones genéticas em familias S4 de maíz (Zea mays). Ciencia e Investigación Agraria, v.33, n.2, p.125-131, 2006. https://doi.org/10.7764/rcia.v33i2.335

BALESTRE, M.; VON PINHO, R. G.; SOUZA, J. C. Prediction of maize single-cross performance by mixed linear models with microsatellite marker information. Genetics and Molecular Research, v. 9, n. 2, p. 1054 1068, 2010. https://doi.org/10.4238/vol9-2gmr791

BARRETO, R. R.; SCAPIM, C. A.; AMARAL JÚNIOR, A. T.; RODOVALHO, M. A.; VIEIRA, R. A.; SHUELTER, A. R. Avaliação da capacidade de combinação de famílias S2 de milho-pipoca por meio de diferentes testadores. Semina, v. 33, n. 3, p. 873-890, 2012. https://doi.org/10.5433/1679-0359.2012v33n3p873 
BERNARDO, R. Best Linear Unbiased Prediction of Maize Single-Cross Performance. Crop Science, v. 36, $\mathrm{n}$. 4, p. 50-56, 1996.https://doi.org/10.2135/cropsci1996.0011183X003600040007x

BORGES, V.; FERREIRA, P. V.; SOARES, L.; MARTINS, G.; MARIA, A.; SANTOS, M. Seleção de clones de batata-doce pelo procedimento REML/BLUP. Acta Scientiarum Agronomy, v. 32, n. 4, p. 643-649, 2010. https://doi.org/10.4025/actasciagron.v32i4.4837

CRUZ, J. C.; PEREIRA FILHO, I. A.; BORGHI, E.; SIMÃO, E. P. Quatrocentos e setenta e sete cultivares de milho estão disponíveis no mercado de sementes do Brasil para a safra 2015/16. Sete Lagoas: Embrapa Milho e Sorgo. 2015. 21 p.

CRUZ, C. D.; REGAZZI, A. J.; CARNEIRO, P. C. D. Modelos biométricos aplicados ao melhoramento genético - Volume 1. Viçosa: UFV. 2012. 514 p.

DE CARVALHO, M. S. N.; MANGOLIN, C. A.; SCAPIM, C. A.; DA SILVA, T. A.; MACHADO, M. F. P. S. A collection of popcorn as a reservoir of genes for the generation of lineages. Molecular Biotechnology, v. 53, n. 3, p. 300-307, 2013. https://doi.org/10.1007/s12033-012-9527-6

FREITAS, I. L. J.; AMARAL JUNIOR, A. T.; VIANA, A. P.; PENA, G. F.; CABRAL, P. S.; VITTORAZZI, C.; SILVA, T. R. Ganho genético avaliado com índices de seleção e com REML/Blup em milho-pipoca. Pesquisa Agropecuária Brasileira, v. 48, n. 11, p. 1464-1471, 2013. https://doi.org/10.1590/S0100204X2013001100007

FRITSCHE-NETO, R.; GONÇALVES, M. C.; VENCOVSKY, R.; SOUZA JUNIOR, C. L. Prediction of genotypic values of maize hybrids in unbalanced experiments. Crop Breeding and Applied Biotechnology, v. 10, n. 1, p. 32-39, 2010. https://doi.org/10.12702/1984-7033.v10n01a05

GRIFFING, B. Concept of general and specific combining ability in relation to diallel crossing systems. Australian Journal Biology Science, v. 9, n. 4, p. 463-493, 1956. https://doi.org/10.1071/BI9560463

HENDERSON, C. R. Applications of linear models in animal breeding. Guelph: University of Guelph. 1984. $462 \mathrm{p}$.

JI, H. C.; CHO, J. W.; YAMAKAWA, T. Diallel analysis of plant and ear heights in tropical maize (Zea mays L.). Journal of the Faculty of Agriculture Kyushu University, v. 51, n. 2, p. 233-238, 2006.

LEONELLO, L. A. F.; CAZETTA, D. A.; FILHO, D. F. Características agronômicas e qualidade comerciai de cultivares de milho pipoca em alta população. Acta Scientiarum Agronomy, v. 31, n. 2, p. 215-220, 2009.

OLIVEIRA, G. H. F.; BUZINARO, R.; REVOLTI, L. T. M.; GIORGENON, C. H. B.; CHARNAI, K.; RESENDE, D.; MORO, G. V. An accurate prediction of maize crosses using diallel analysis and best linear unbiased predictor (BLUP). Chilean Journal Agricultural Research, v. 76, n. 3, p.294-299, 2016. https://doi.org/10.4067/S0718-58392016000300005

PIMENTEL GOMES, F.; GUIMARÃES, R. F. Joint analysis of experiments in complete randomised blocks with some common treatments. Biometrics, v. 14, n. 4, p. 521-526, 1958. https://doi.org/10.2307/2527518

R CORE TEAM. R: A language and environment for statistical computing. R Foundation for Statistical Computing. 2016.

RESENDE, M. D. V. Genética biométrica e estatística no melhoramento de plantas perenes. Brasília: EMBRAPA. 2002. 975 p. 
ROSSATO JUNIOR, J. A. S.; CAZETTA, D. A.; BARBOSA, J. C.; FILHO, D. F. Popping expansion and yield responses of popcorn cultivars under different row spacing's and plant populations. Pesquisa Agropecuária Brasileira, v. 48, n. 12, p. 1538-1545, 2013. https://doi.org/10.1590/S0100204X2013001200002

SANTOS, O. J.; GONÇALVES, L. S.; SCAPIM, C. A.; SM, D. S.; CASTRO, C. R.; \& DE OLIVEIRA, A. L. Screening of inbred popcorn lines for tolerance to low phosphorus. Genetics and Molecular Research, v. 15, n. 2, p. 1-9, 2016.

SAS® 9.4. Cary, North Carolina, USA: SAS Institute Inc. 2013. https://doi.org/10.4238/gmr.15027519

SCHRAG, T. A.; MÖHRING, J.; MAURER, H. P.; DHILLON, B. S.; MELCHINGER, A. E.; PIEPHO, H. P.; SORENSEN, A. P.; FRISCH, M. Molecular marker-based prediction of hybrid performance in maize using unbalanced data from multiple experiments with factorial crosses. Theoretical and Applied Genetics, v. 118, n. 4, p. 741-751, 2009. https://doi.org/10.1007/s00122-008-0934-9

SILVA, V. Q.; AMARAL JÚNIOR, A. T.; GONÇALVES, L. S.; FREITAS JÚNIOR, S. P.; CANDIDO, L. S.; VITTORAZZI, C.; MOTERLE, L. M.; VIEIRA, R. A.; SCAPIM, C. A. Combining ability of tropical and temperate inbred lines of popcorn. Genetics and Molecular Research, n. 9, v. 3, p. 1742-1750, 2010. https://doi.org/10.4238/vol8-3gmr900

SILVA, T. R. C.; AMARAL JÚNIOR, A. T.; GONÇALVES, L. S. A.; CANDIDO, L. S.; VITTORAZZI, C.; SCAPIM, C. A. Agronomic performance of popcorn genotypes in Northern and Northwestern Rio de Janeiro State. Acta Scientiarum Agronomy, v. 35, n. 1, p. 57-63, 2013.

https://doi.org/10.4025/actasciagron.v35i1.15694

VIEIRA, R. A.; SCAPIM, C. A.; TESSMANN, D. J.; HATA, F. T. Diallel analysis of yield, popping expansion, and southern rust resistance in popcorn lines. Revista Ciência Agronômica, v. 42, n. 3, p. 774-780, 2011. https://doi.org/10.1590/S1806-66902011000300025 